\title{
National feeling or responsibility: The case of the Csángó language revitalization*
}

\author{
KLÁRA SÁNDOR
}

\begin{abstract}
During the past decades several attempts have been made in various parts of the world to revitalize languages whose speakers are constantly decreasing. Such an attempt was also made in Hungary and the Hungarian-speaking regions of Rumania in the 1990s, when some people attempted to revitalize the one-time Hungarian mother tongue of the Csángós, an originally Hungarian-speaking group which has lived for centuries in isolation from the other Hungarian-speaking regions. The majority of the Csángós are monolingual Rumanian speakers today but some of them still speak their Csángó dialects of Hungarian origin. As part of the revitalization program, Csángó youths were taken to Hungarian schools and universities in Transylvania (Rumania) and Hungary to learn Hungarian. After a brief introduction of the Csángós, this paper analyzes the reasons why this schooling action was doomed to inevitable failure. The program suffered from a lack of linguistic and pedagogical planning, and those involved in its implementation disregarded the linguistic, cultural, social, and economic differences between the Csángós and the Hungarians.
\end{abstract}

\section{Introduction}

In Rumanian Moldavia, in the foothills of the Eastern-Carpathians and in the valley of the River Siret (Hungarian Szeret) lives the ethnic group known as the Csángó [ča:ngo:]. In Robin Baker's (1997: 658) phrasing they are 'one of Europe's most enigmatic and least known ethnic minorities'. According to widely accepted estimates the number of Csángós is about 240,000. ${ }^{1}$ They live in about 90 villages scattered mostly around Roman (Hungarian: Románvásár) and Bacău (Hungarian Bákó). Their forefathers were Hungarians, but now most of them have shifted language and speak Rumanian as their mother 
tongue. However, about 62,000 of them still speak vernacular dialects of Hungarian origin (Tánczos 1997: 379). Although the Csángós thus do not share a common vernacular anymore, they are distinguished by their religion from the other ethnic groups in Moldavia.

From the 17th century onward the Csángós have been rather isolated from the main Hungarian speaking area (i.e., the Carpathian Basin), and as a consequence they speak dialects which sound archaic to other speakers of Hungarian. Their history in Moldavia has also preserved their culture in a form that is reminiscent of the 17-18th centuries. In periods when the question of the 'nation' is the focus of Hungarian political ideology, this archaic culture and language fascinates politicians and laymen, as for example, in the 1990s. Although this form of enthusiastic interest has always produced negative results (cf. Sándor 1998b), politicians in Hungary and in the part of Rumania known as Transylvania do not seem to have learnt from their failures in this respect, and many scholars dealing with the Csángós have acted on the basis of their emotions rather than their knowledge in attempting to 'rescue' the Csángós. These 'rescues' appear in varying forms. The present paper focuses on one which can be labeled as an attempt to revitalize the Csángós' language. My aim is to show that the fiascos which this process have resulted in were necessary consequences of ideological and political interference and neglect of linguistic, cultural-historical, and anthropological arguments.

\section{A brief overview of the history of the Csángós and the current situation}

In the middle of the 14th century the Hungarian king, Louis the Great (13421382) defeated the Mongols of the Golden Horde (Lükö 1935: 96; Baker 1997: 667), pushed them back to the eastern side of the Dnester, and aimed to establish a buffer state between his kingdom and the Tatars. (There are several other ideas about the origins of the Csángós, which are summarized and convincingly refuted by Baker 1997.) With the agreement of the king, Dragoş, the Voivode ('ruler') of the Rumanians in Maramureş, moved to Moldavia and founded the Moldavian Principality in the 1350s.

As dialect history (Benkő 1989) and ethnography (Lükő 1936) prove, at the same time a large group of Hungarians moved to Moldavia from the northern part of Transylvania which is called Mezöség, a neighboring area with Maramureş. These Hungarians settled in North-West Moldavia (Lükö 1936: 33-36; Benkö 1989: 405). They soon populated the lower Siret area, their villages forming a continuous chain from Suceava down to the Trotuş (Hungarian Tatros, Benda 1989: 24, 29; for the toponymic data see Benkö 
1989: 279-283). From the 14th to the 16th centuries Hungarians played an important role in the life of the court of the Moldavian Voivode and also took a significant part in the social and economic life of Moldavia (Benkö 1989: 287). ${ }^{2}$

However, most of the Hungarians lived in villages, doing agricultural work (Benda 1989: 35-37; Lukő 1936: 14-15). Their communities were independent from anyone but the Voivode, they owned their fields, and selected their judges for themselves (Mikecs 1989: 160-161; Benda 1989: 38-39). Up to the end of the 16th century the number of Moldavian Hungarians increased, and they also founded new villages east of the Siret and around Bacău (Benda 1989: 30-31; Lükő 1936: 37). The Hungarian Kingdom had significant military and religious influence in the area until the 16th century, when west and central Hungary were occupied by the Habsburg and the Ottoman Empires, respectively. The 17th century saw a dramatic turn in the life of the Moldavian Hungarians. Moldavia became an area of war for Ottoman (Crimean Tatar), Wallachian and Hungarian troops, towns were demolished, poverty and disease killed many people. The Moldavian Hungarians then became permanently isolated from the Hungarian language and culture of the Carpathian Basin when in 1622 the Vatican took over all the Catholic activities in Moldavia, and sent Italian and Polish priests to the Moldavian Hungarian villages (Benda 1989: 42).

The sense of isolation continued to be strong during the following centuries, in spite of the fact that more and more Hungarian refugees arrived in Moldavia from the other side of the Carpathians. These were Székelys, members of a strong community living in Eastern Transylvania. The Székelys enjoyed the privileges of collective nobility, they had their own autonomous military and jurisdictional areas, and were freed from paying taxes either to the royal court or to the Voivode of Transylvania. The notion of collective nobility, however, did not mean equal rights and equal prosperity within the community, and from the 18th century on the Habsburg rulers tried to integrate the Székelys into the Empire and deprive them of their privileges. So both economic and political factors motivated the migration to the east. The Székely groups settled in a large eastern-southern strip around Bacău, either in newly founded villages, or in the villages of the earlier Hungarian settlers.

In the 19th century the isolation was completed by a conscious assimilation policy on the part of the new Rumanian nation state. This policy was actually based on the very similar assimilating techniques of the Catholic Church whose interest has also been to have Rumanian Catholics. Since the Church has absolute power in the life of the Csángós, this policy continues to be extremely powerful and has significantly accelerated the language shift of the Csángós (see Sándor 1996b). The assimilating force of the Catholic 


\section{K. Sándor}

Church was also strengthened by the schools. Towards the end of the 19th century schooling became widespread in Moldavia, and since then the language of education has always been Rumanian (except for a short period between 1947 and the 1950s when Hungarian could also be used as the language of instruction). In most of the schools, speaking Csángó has always been forbidden even in the breaks. It also means that for the Csángós the exclusive language of literacy is Rumanian.

Now, at the end of the 20th century, the Csángós still have no minority status in Rumania. Consequently they have no right to use their mother tongue and to keep their culture. In the phrasing of a Csángó teacher who lives in Transylvania today, the assimilating process which is being carried out in Moldavia is 'a terrible psychological and spiritual genocide' (quoted by Borbáth 1996: 217). The great mass of the Csángós do not even realize what is happening to them since the state uses the Church, the most respectable authority in the eyes of the Csángós, as a means of assimilation. The Moldavian Catholic priests humiliate those who keep any connections with Transylvania or Hungary (cf. Sándor 1999). In the Csángó villages teachers still forbid the use of Csángó dialects, arguing that if the pupils live in Rumania they must speak Rumanian and that their mother tongue is a deficient, useless 'mongrel', a 'bird's language'. People teaching children Hungarian in their own houses can be accused of having violated the constitution (cf. Csapó 1994; Pálffy 1997: 68), etc. ${ }^{3}$ Considering the events of the last few years, it can be stated that the Csángós do not have any linguistic human rights.

The present life of the Csángós seems very archaic to outsiders. Theirs is a way of life in which economy, daily life, material and spiritual culture cannot be separated from each other but constitute an integral, organic unit harmonized by their religion. Even the most secular aspects of Csángó life are pervaded by their faith (Tánczos 1995a: 20-21; Magyar 1994: 77), and the communication with the metaphysical world is as natural a part of this life as is mysticism and the daily practice of folk beliefs (cf., e.g., Virt 1994; Nyisztor 1997; Pozsony 1997b). Communities freeze out people who do not follow the strict religious prescriptions, to this day (Kotics 1997). Disrespect of religious morals is severely punished by the priests publicly humiliating people, and sometimes excommunicating them from the church (Kallós 1993: 101). Normally it is the priests who have social control in the Csángó communities as individuals (Kotics 1997: 49-50), otherwise the social control is practised by the community itself. As all activities and symbols have metaphysical meaning, the tradition has conserved an archaic rural culture. Folk art and folklore are not ancient relics but an integral part of the everyday life of the Csángós. 
According to the anthropologist János Benedek (1997a: 195), the frame of Csángó society is still today a pre-industrialized rural society which harmonizes with the medieval-like worldview of the Csángós. The great mass of the Csángó population are peasants who own and cultivate their own fields. The methods of agricultural production are rather undeveloped, lacking almost any mechanization. Until very recently the Csángós had an almost totally subsistence economy. Actually, they still identify subsistence with independence today, and look upon it as the ideal model of living (Benedek 1997b: 220). The Csángós have no handicraft industry; manufacturing is only the completion of agricultural work (Benedek 1997a: 205, 208; Halász 1994: 21). In the West European sense of the word there is no stratification in the Csángó communities. There is no nobility, there are no craftsmen, merchants, civil servants, and there is no intelligentsia. People differ from each other according to their relationships and wealth. The basis of the organization of the Csángó society is kinship (Halász 1994: 27).

The culture of the Csángós was developed and preserved by their isolated life. They were segregated from their Orthodox Moldavian neighbors on the basis of their religion, and they were isolated from the Carpathian Basin Hungarians. Their isolation started to loosen in the 1960s, when urbanization also reached Moldavia. From this time on Csángó men, and especially young people have tried to find jobs in a nearby town (Pozsony 1997b: 248). This fact, however, did not change the structure of the Csángó economy. Women stayed in the villages, and the Csángós still keep to agricultural work as the basis of their existence (Benedek 1997a: 197-198). At the same time, urbanization has caused more significant changes in the culture. Respect for traditional values and morality is still exclusive for the elder generations (Tánczos 1995a: 286), but among the younger ones a mixing of traditional and 'modern' values can be detected (Kotics 1997: 47). The co-existence of the traditional and the 'civilized' world is characteristic of almost all aspects of life (cf., e.g., Pozsony 1997a: 246-247; Tánczos 1996: 106, 118, 151). Moreover, some young people working or studying in the towns disrespect the old traditions (Seres 1994: 113). According to Magyar (1994:87), the traditional spiritual and material culture of the Csángós is beginning to crumble.

\section{The linguistic situation of the Csángós}

The dialects and the sociolinguistic situation of the Csángós are characterized by the same attributes as their culture and social situation. Csángó villages were originally easily distinguished according to their Székely or non-Székely dialects. The 14-15th century settlers from the Mezőség populated the 
area which surrounds the town of Roman, and as the population grew constantly, new villages were settled in a southerly direction, along the river Siret, in the area which surrounds the town of Bacău. Dialects spoken by the descendants of these settlers are usually called Northern (Hungarian-)Csángó (around Roman) and Southern (Hungarian-)Csángó (around Bacău) often with a collective name Hungarian-Csángó, while dialects spoken by the descendants of the Székelys are called Székely-Csángó. There are significant phonetic, syntactic, and lexical differences between Northern and Southern Csángó dialects, on the one hand and Székely Csángó dialects, on the other. (Table 1. shows some of the most characteristic markers.)

However, in the Southern-Csángó area, where the Székely and nonSzékely population mixed with each other, their dialects have also interacted with each other. In this area the classical features of Hungarian and Székely Csángó dialects do not make bundles of isoglosses, that is, no sharp distinctions can be made regarding all the features at the same time. As, for historical reasons, the Székely Csángó dialects are more prestigious, it is quite predictable that some of the features of Hungarian Csángó, like the so called 'lisping' (the result of the merger of $/ \mathbf{s} /$ and $/ \check{\mathbf{s}} /$ can be stigmatized. Lükő (1936: 53-54), for one, reports on the stigmatization of the non-Székely features, and mentions clear cases of hypercorrection to avoid stigmatized 'lisping' in the speech of villages with mixed population. Still, because of the lack of proper data, ${ }^{4}$ it is not known where certain features are stigmatized, or even where specific features do not even exist anymore. Interviews made in

Table 1. The most characteristic differences between the Hungarian-Csángó and the Székely-Csángó dialects

Hungarian-Csángó

/s/and /š/ merged to palatalized /ś/

[č] shifted to be palatalized

[d'] and [t'] shifted to [îj] and [ᄃ̌c]

$/ l^{\prime} /$ and $/ \mathrm{j} /$ are opposing phonemes

$/ e /$ and $/ \varepsilon /$ merged to $/ \varepsilon /$

/o/ and $/ \square /$ merged to/ ) /

the long close-mid vowels are diphthongs

the suffix $-v V l$ ' with' does not assimilate

(ember 'man' + -vel 'with' $\rightarrow$ embervel)

the auxiliary verb for conditional is lenne

lexical differences, like e.g.

filesz 'rabbit'

fel 'fat'

tyuhnon 'egg'

\section{Székely-Csángó}

$/ s /$ and $/ \check{\mathrm{s}} /$ are opposing phonemes

[č] is not palatalized

[d'] and [t'] stayed plosives

$/ \mathrm{l} /$ and $/ \mathrm{j} /$ merged to $/ \mathrm{j} /$

le/ and $/ \varepsilon /$ are opposing phonemes

$/ o /$ and $/ \square /$ are opposing phonemes

the long close-mid vowels are monophthongs

the suffix $-v V l$ 'with' assimilates to the final

$\mathrm{C}$ of the stem (ember + -vel $\rightarrow$ emberrel)

the auxiliary verb for conditional is volna

nyúl 'rabbit'

zsir 'fat'

tojás 'egg',etc.

Csángó villages ${ }^{5}$ prove that 'lisping', for instance, can totally disappear while other features which seem to be combinatory with 'lisping' on a phonological basis, like the palatalization of [č ], are preserved. In other villages it can vary according to different rules, and other variables are governed by different 
rules again. As the Csángó villages are still rather isolated from each other, practically all Csángó villages have their own, significantly distinct dialects.

The diversity of the Csángó dialects is even more colored by the fact that they are differently influenced by Rumanian, i.e., they differ from each other also on the basis of the number and distribution of contact induced forms. According to Tánczos (1995b: 62) at the end of the 20th century there are about 50-60 Csángó bilingual villages, almost exclusively in the Southern and Székely Csángó area. Historical sources prove that in the Northern Csángó area only about 25-30 percent of the population spoke Hungarian dialects in the middle of the 19th century. In bilingual Northern Csángó villages bilingualism strongly tends towards monolingualism. Language shift is probably in its last stage in the area. The Southern Csángó and the Székely Csángó dialects were maintained relatively successfully until about the 1930s when language shift also accelerated in these areas (for reasons see Sándor 1996b). Community bilingualism is still characteristic of the Southern Csángó villages. Moreover in some Székely Csángó villages even monolingual Csángó speakers can be found among elderly women, but today there are only a very few Székely Csángó villages (Tánczos 1995b: 62 considers only four) where the mother tongue of the youngest generation is Csángó and not Rumanian. According to different indexes of bilingualism (i.e., the percent of bilingual individuals in the community, the distribution of the two languages in domains of language use, etc.), the Csángó villages differ from each other. Dialects of the Northern Csángó area show the heaviest influence, dialects of the Southern Csángó area less, and dialects of the Székely Csángó villages the least impact of Rumanian.

The diversity of the Csángó dialects has produced a situation such that between some of the dialects there is no mutual intelligibility. In addition, Csángós usually have very negative attitudes towards their dialects (we shall return to the reasons for this later). A sociolinguistic result of these factors is that Csángós coming from different villages and speaking with each other usually switch to Rumanian.

Nevertheless, all the Csángó dialects have some common features which differentiate them from the Carpathian Basin Hungarian dialects. Such features are for instance the attributes of all peripheral dialects, i.e., the maintenance of archaic grammatical forms and words, and the development of new forms, independently of the central dialects, as well as the bulk of contact phenomena as a natural consequence of the wide-spread bilingualism. The Csángó dialects have always been roofless dialects, unaffected by standard Hungarian, which was developed in the 19th century. For speakers of Hungarian the intelligibility of Csángó dialects varies from village to village; most are very or totally incomprehensible to them. Csángós do not understand, or understand only with great difficulty, Hungarian varieties. 


\section{The Csángó schooling action}

In 1990, in the euphoric atmosphere of political changes in Hungary and Rumania, as part of an initiative by the Democratic Federation of Hungarians in Rumania, Csángó pupils were brought to Hungarian schools in Transylvania, and Csángó young people were sent to Hungary to get their education there. This program aimed at educating a first generation of Csángó intelligentsia, and was based on the presupposition that the Csángós belonged to the body of the Hungarian nation, so that it was a great opportunity that, after centuries of subjugation of their mother tongue, they can now be educated in Hungarian. The action was supposed to be the first step towards the mother tongue education of the Csángós, and its organizers hoped that it would stop language shift among the Csángós. So the action had ambitions similar to those of language revitalization programs. ${ }^{6}$

In the first year of the action (1990) about 30 pupils aged 10-13 were brought to 6 (Hungarian-dominant) Transylvanian towns. They were introduced into the classes of their age-groups. However, it soon turned out that this method did not work. The Csángó pupils were not able to integrate with their classmates. Most of them remained segregated, and many of them went back to Moldavia before the end of the school year. From 1991 on, only one Transylvanian school, the József Attila School in Csíkszereda (Rumanian Miercurea Ciuc) took Csángó pupils of 13 years for a two year program. In this school a separate class was organized for them. This program seemed to be successful: 40-50 percent of the Csángó pupils continued their education in different Transylvanian highschools and vocational schools, and by 1993 the number of Csángó pupils studying in Transylvanian schools had doubled. In 1994 altogether 220 Csángó pupils and highschool students studied in Transylvania, most of them in Csíkszereda (Borbáth 1996: 70-71, 73-74; Pálffy 1997: 60-61). However, from 1995 onwards this number decreased significantly, and in 1997 no Csángó class was organized in the József Attila School. By that time it became obvious that the Csángó schooling action, at least at the elementary and intermediate level, had failed. Those who went back to Moldavia after their study could not get jobs there, but most of them did not even want to go back (Borbáth 1996: 71). Actually their old communities did not accept the students either (Pálffy 1997: 67). After the years they spent in Transylvania, the young Csángós could not reassimilate into their Moldavian communities, but they could not successfully assimilate to the Transylvanian environment either. These failures disappointed not only the Csángós but also their teachers.

The story of the Csángó young people who were taken to Hungary is very similar. Many of them did not finish their education; those who did tried to stay in Hungary or in Transylvania and did not go back to Moldavia. The very 
few who wanted to live in their homeland could not get jobs there. During their studies the Csángó students had serious problems with integration into the Hungarian society. They met incomprehension and ignorance on the side of the accommodating communities (including their teachers), as did the pupils and students in Transylvania.

In an analysis of the Transylvanian part of the Csángó schooling action Pálffy (1997: 71) labels it a 'psychological and social ordeal' for the Csángós that again added a bitter experience to the feeling of being Csángó. This opinion seems to be painfully applicable also for the Hungarian part of the action. However, the misfortunes of the action surprised only those who took it for granted that learning or studying in Hungarian can only be felicitous for the Csángós, and who, intoxicated by the possibility of action, did not have a plan for the subsequent years of the action or pay attention to the conditions in which the action was introduced. If they had considered the situation, they would not have taken the responsibility for starting the action, since the fiasco was clearly predictable.

\section{Why the Csángó schooling action failed}

The failure of the Csángó schooling action can be attributed to two general causes. One is the irresponsibility with which the action was carried out, the other is the lack of knowledge about the Csángós.

It was irresponsibility that the action was not prepared in any way, neither pedagogically nor financially. Teachers who had to teach the Csángó pupils and students could not know more about the cultural, linguistic, and social background of their students than anybody else in Transylvania or Hungary, i.e., they knew very little about the Csángós. The teachers were put into a special pedagogical situation, and had no training for problems they faced, namely that the Csángó pupils and students arrived from different villages, with different dialectal and educational backgrounds. The Csángó students, certainly, could write and read only in Rumanian, and in addition even the way they spoke sounded extremely 'strange'. (It definitely was far beyond the border of the dialectal speech that a Hungarian teacher, living and educated in a linguistically very normative society, could tolerate.) The Csángó students, of course, had no possibility of acquiring even an elementary knowledge of Hungarian literature and history and compared to the Transylvanian and Hungarian students, they had shortcomings in other subjects, too. Nonetheless, the selection was not founded on any criteria, and the organizers of the action recruited the Csángó pupils and students arbitrarily, without any communication with the schools. Teachers had no time for preparing, getting information, and working out programs. It was a 
total surprise to them that they were to teach Csángó students. The teachers at the József Attila School, for example, learned during their first meeting at the beginning of the school-year that the Csángó pupils and their parents were waiting for them in the school hall. The pedagogical unpreparedness of the schooling of course afflicted the pupils and students even more strongly.

The funds the schooling action were built on were insufficient, too. Many Csángó families allowed their children to learn in Transylvania in the hope of ensuring a higher standard of life for them, at least for their study years. It is sad that even those circumstances in which the Csángó children were living in their Transylvanian hostel could fulfil these expectations. It cannot mean, however, that it was fair to accommodate the Csángó pupils at a place that was very much under the level of other Transylvanian pupils' hostels. 20-30 children lived here in one room, and no private educator could be employed for them, although from a pedagogical point of view, it would have been more than reasonable. Even this small budget disappeared for the second year of the action, when the Transylvanian Catholic Church, which guaranteed the expenses in the first year, simply quit. From 1991 on it depended on the head of the József Attila School alone, as to whether the Csángó pupils could finish their education in Transylvania. If she is clever enough to gather the required amount of money for the foundation that she established for this purpose, they can; if she has no more energy for doing it, they cannot. ${ }^{7}$

The Csángó students in Hungary found themselves in a very similar situation regarding pedagogical and financial deficiencies in their studies. They spent their first year in a language school established for teaching Hungarian to foreigners who want to study in Hungary. The idea that the Csángó students should learn some Hungarian before starting the university could have been a useful one, since Csángó dialects differ significantly from Hungarian varieties. But needless to say courses which were designed for people whose mother tongue had nothing to do with Hungarian, could not be appropriate for the Csángós (except for those whose mother tongue was Rumanian). The financial deficiencies in their case, if at all possible, were even more obvious and embarrassing. The Csángó students were accommodated in the college of the language school, on the edge of Budapest. The college itself meets the average Hungarian hostel norms, but the students were confined there as if to a ghetto since the Csángó students had practically no stipend. In the academic year 1995/96 for instance, after having paid the accommodation and meal costs, the sum they could save was not enough to go into the city of Budapest more than 2-3 times a month. Only after this first year, if they still wanted to stay in Hungary at all, and if they completed a successful entrance examination to a university, did they get the same state allowance as minority Hungarians coming from Slovakia, Ukraine, Serbia and Transylvania. 
Besides the pedagogical and financial thoughtlessness, the organizers of the Csángó schooling action made the worst mistake when they failed to consider whether the Csángó students and pupils would psychologically survive their own 'rescue'. In other words, when the organizers, instead of gathering information, took it for granted that the Csángós could only benefit from learning in Hungarian. Behind this carelessness one may presume there lay an appalling lack of knowledge about the Csángós.

There was forewarning. First of all there were the difficulties in convincing the Csángó parents of the advantages of studying in Transylvania. The organizers of the action ignored this resistance, assuming that the Csángós' resistance was due to the influence of Rumanian propaganda against the Hungarians. They argued for the education of a Csángó intelligentsia in Hungarian schools and universities with exactly the aim of counteracting this effect. True enough, the assimilation policy of the Rumanian state is highly sophisticated. No sober analysis can deny that the Csángós are frightened of using their vernacular dialects, and that they have good reason for feeling so. Consequently, no request for the Csángós' human rights, including linguistic human rights can be superfluous. But this is only one side of the coin. No actions related to the Csángós can be planned without regard to the fact that the assimilation policy does exist, and that, moreover, that this policy prevails. Many Csángós are afraid of anything associated with Hungarians, and this was obviously one of the reasons why parents did not want to let their children go to Transylvania (cf. Borbáth 1993: 93). Many Csángós are also convinced that they do not need to keep con-nections with Hungarians either in Transylvania or in Hungary, and ostracize those who have studied there (Pálffy 1997: 67, 70). In brief, whatever the reasons, it is a fact that there are many Csángós who have anti-Hungarian feelings (about its forms see Tánczos 1995a: 155; 1996: 102-105, 113, 137, 255).

The other thing one must face is that Rumanian propaganda is only one source of the anti-Hungarian feelings of the Csángós. The other source is what Tánczos (1996: 184) calls 'the Székely nationalism that disdains the Csángó'. It is less known in Hungary that the Székelys hold very strong prejudices about the Csángós. That can be illustrated among other things with the saying 'not a human being, just a Csángó', or with the popular folk etymology of the name Csángó, namely that according to the Székelys the name refers to those people whose speech sounds unpleasant, who cannot speak proper Hungarian. The belief that the Csángós 'deserve' their name is so deeply established that even the Csángós have learnt it from the Székelys. Today the Csángós evaluate the differences between their own dialects and the Székely ones as deficiencies, and they are ashamed of using a 'corrupted' mother tongue. Thus, to avoid mockery, they switch to Rumanian in the presence of Székelys (cf. Bihari 1994). Just as the Székelys' prejudices about 


\section{K. Sándor}

the Csángós are strong, so is the Csángós' inferiority complex towards the Székelys strong also. No wonder that after a long history of humiliation the Csángós loathe the Székelys.

The organizers of the Csángó schooling action disregarded the traditional hostility between the 'rescuees' and the accommodating community, and let the Csángó children in for a bitter experience. It happened that Csángó pupils in Transylvania were insulted on the street by some people only because of being Csángó (Pálffy 1997: 66). The pupils also often observed the opposite as other people showed extraordinarily compassionate feelings to them. Since the pupils could not find a motivation for this unexpected kindness, they felt it embarrassing (Pálffy 1997: 69).

The Csángó students in Hungary also met apparently unmotivated kindness but also, unlike in Transylvania, wide-eyed astonishment. Those who had heard about the Csángós before handled them with embarrassing care and adoration, while, at the same time, many people, including the Csángó students' teachers, knew hardly anything about them. One of my Csángó students understood that, amazed by his speech, people let him speak to try and find out, 'what kind of alien from Mars' he was (his phrasing), 'speaking a Hungarian which is not Hungarian'. Even their teachers, at least many of them, did not know that the Csángós lived in Moldavia and not in Transylvania, and expected the Csángós to speak 'proper' Hungarian (Fodor had similar experiences 1995: 125-126). The students certainly felt lost in this world of contraries, they could understand neither the endearment nor the incomprehension, and especially not the strange mixture of the two. The phenomena they had to face left deep and painful impressions in them.

The organizers of the schooling action were ignorant not only of the relationship between the Csángó students and the accommodating communities, but also of the living conditions and culture of the Csángós. Although Csángó culture has begun to change in the last few decades, it is very distant from the Transylvanian and especially from the Hungarian way of life. The differences are so remarkable that the Csángó pupils and students experienced the deepest culture shock on this basis alone. Urbanization and modernization are causing a crisis of values and social friction in Moldavia (Bihari 1994), but the effect was even more powerful in the new environment which was seen by the Csángós as 'highly developed' and 'modern'. In the 'splendor' of 'civilization', their own culture, values and moral seemed to be backward, old-fashioned, and out of date, and they were entirely defenseless against the symptoms of civilization. The financial differences between home and the new environment strengthened their well established inferiority complex, and removing them appeared to the students to be a prerequisite for integration. To achieve this financial goal was for many more important than $j$ anything else, including studying, and they took hard physical jobs. In J 
addition, a preference for 'real work' tallies with the Csángó scale of values, in which reading, learning, arts, and sciences are considered to be useless activities done by lazy people instead of real, i.e., manifestly productive, work. In the worst cases, especially in Budapest, they got involved with the criminal underworld (Bihari 1994). In such circumstances they did not have enough time to study, and, seeing the requirements and lacking real motivation, many of them were not even inclined to do so. ${ }^{8}$

Another factor also made the Csángó students' situation rather difficult. Their education and knowledge of general culture was at a lower level in all subjects than their classmates' (Borbáth 1996: 72), but the real difficulties they had were with Hungarian literature, grammar and history, as they simply could not learn these subjects in Moldavia. Most of their Hungarian teachers did not know about this circumstance, so they were unable to understand their pupils' deficiencies. The problem was especially serious because the Csángó students were supposed to study at Hungarian schools and universities primarily for the sake of these subjects. Consequently, the Csángó students often fell victim to the mistaken imputation by their teachers that their lacunae in the 'national subjects' were due to their laziness or even corrupted morality (cf. Pálffy 1997: 68, 72-73).

\section{Could an alternative schooling action have been successful?}

Any of the problems listed is serious enough to interfere with the plan of the Csángó schooling action. However, with cautious planning and careful preparatory work these problems might have been overcome. On the other hand, there are two further factors which would seem to be insurmountable obstacles for Csángó schooling actions in Transylvania or Hungary. These factors are closely associated with the basic presuppositions of the action, namely that the Csángós are Hungarians so they will definitely benefit from education in Hungarian. The organizers of the action disregarded the fact that most of the Csángós do not share these notions.

Many Csángós do not even understand what they have to do with Hungary and the people living there. The organizers of the action wanted to strengthen the Hungarian national feeling on the part of the Csángós, but in most cases it still needed to be created in the first place, since the Csángós did not participate in the formation of the Hungarian nation that happened in the first half of the 19th century, long after the last Csángó migration to Moldavia. As a consequence, they do not know the elements which constitute the core of Hungarian national feeling, such as knowledge of and respect for a shared language and history, or the great personalities of the national pantheon; or a knowledge of and pride in the canon of Hungarian literature, arts, and 
sciences. They also do not know the symbols that represent these elements, even the most basic ones such as the national anthem, the coat of arms of Hungary, the national days, etc. The Csángós know very little about Hungarian history, no more than they can learn in the Rumanian schools. If they learn about their own history at all, it is according to the official concept of the Rumanian state, in which the Csángós are Hungarianized Rumanians. Only very few Csángó students have been able to learn from their grandparents that the Csángós had some connections with the Hungarians.

Moreover, many of the Csángós learn only as teenagers or young adults that they are actually Csángós. This may seem curious but the Csángós are loath to transmit their name to their children for well established historical reasons. The Csángós lack a common 'we-consciousness' first because their ancestors arrived in Moldavia at different periods and with different cultural and dialectal backgrounds. Integration was then hindered by the geographical location of the villages, as they did not form a cohesive unit and by the political and economic autonomy of the villages as well. For a long time the Moldavian Hungarians of Székely and non-Székely origin sharply differentiated themselves from one another (for the main features see Lükő 1936). This differentiation is loosening up in our days, the division by origin and culture being replaced by a division according to the geography of the Csángó villages (Halász 1997). However, because this process is a consequence of the weakening of traditional rules and thus also causes cultural assimilation, the only factor on which the newly developing Csángó we-consciousness can be established, is solidarity based on the shared experience of segregation from Rumanian society (similarly Tánczos 1996: 155-156).

In accordance with the lack of we-consciousness, the Csángós as a group do not have a self chosen endo-ethnonym. The name Csángó was given to the first Hungarian groups in Moldavia by their Hungarian and Rumanian neighbors, and referred only to the Moldavian Hungarians of non-Székely origin for centuries, signifying the differences between the dialects and culture of the populations of the two large waves of Hungarian migration to Moldavia. Now these differences have lost a lot of their earlier weight, and in connection with this leveling the Moldavian Hungarians of Székely origin have also accepted the name Csángó (Tánczos 1996: 155-156), but the name itself still has a pejorative element. The Csángós evaluate it as being a nickname which points to the 'deficiencies' of their mother tongue. The Székelys' mockery is reinforced by the Rumanians who ridicule the Csángós because of their 'mongrel', 'bird's language'. Due to this belief the Csángós feel ashamed of their own name.

All this does not mean that the Csángós do not identify themselves at all: when a Csángó is asked about his/her nationality, the most likely answer is 'I'm Catholic'. This is a well-known fact both in Hungary and Transylvania, 
and is often used as an argument proving the 'purity' of the Csángós. However, this kind of self-identification sounds so odd and 'romantic' for Hungarian politicians and laymen that they do not seem to take it seriously, and the organizers of the schooling action do not seem to have considered that this special identity is not only special but real, too, with important consequences.

Religion is the main opposition which defines Csángó ethnic identity because this is the only major feature that distinguishes them from their Orthodox Rumanian neighbors who live in a very similar way, and in those areas where the Csángós have shifted their language to Rumanian, Csángós and Rumanians even speak the same language. The roots of this identification reach back to the 17 th century, when, after the assimilation of the German communities, all the Catholics in Moldavia were Hungarians (Benda 1989: 24). At that time the Rumanian words for 'Hungarian' and 'Catholic' became synonyms, as did the respective Hungarian words as well. Catholic priests were called 'Hungarian priests' both by the Csángós and their Rumanian neighbors, even if the priests were Italian, German or Polish. This is the reason why Catholics are sometimes called ungur 'Hungarian' in Rumanian even in villages where noone speaks Hungarian anymore. Later the Csángós accepted Hungarian csángó and Rumanian ceangău as their names, and these words displaced the Hungarian designation magyar'Moldavian Hungarian' and the Rumanian word ungur 'Moldavian Hungarian'. In the meantime most of the Csángós have undergone language shift to Rumanian, and csángó and ceangău today mean 'Moldavian Catholic', irrespective of the mother tongue of the people.

The identification of Csángó and 'Moldavian Catholic' has two results that strongly influence Csángó identity. One is that the attachment to Moldavia and especially to the home village is much more important than in the more abstract Hungarian (or other) national identity. Through their loyalty to Moldavia the Csángó ethnic identity is certainly connected also to the Rumanian environment (as their culture interacts with the Moldavian Rumanian culture as well). This attribute is almost always disregarded in discussions about the Csángós, though some scholars have pointed to its relevance (Lükö 1936: 18; recently Kapaló 1994: 31; and Fodor 1995: 124). In addition, because of the effective assimilating policy of the Rumanian state and the Catholic Church, the Csángós began learning about themselves that they were not Moldavian, not even Roman but Rumanian Catholics. Undoubtedly, the replacing of the word 'Roman' (Rumanian romano) with 'Rumanian' (Rumanian romăn) is not the Csángós' invention but an obligatory assimilation forced both by the Rumanian state and the Catholic Church. ${ }^{9}$ However, since it is this notion that the Csángós learn from the priests whose prestige is unquestionable for them, one should reckon with the 
possibility that there are Csángós in whose identity the doctrine of being Rumanian Catholics plays an important role.

The other result of the identification of Csángó and 'Moldavian Catholic' is that the language of the community is not and cannot be a constituent of Csángó ethnic identity, since, after most of them shifted language, the Moldavian Catholics no longer share a common language. The local dialects, of course, symbolize the local culture and the village community (cf. Sándor 1996b), and through this role they are relevant at a certain level of identity, namely they can order the relationships between the Csángó groups, but they are not suitable for opposing Csángós to non-Csángós.

There seems to be an essential difference between the Csángó and Hungarian (and other national) identities that sets a bar against all the attempts to 'teach' the Csángós how to be Hungarians. Since the Csángós did not take part in the formation of any nation, Csángó ethnic identity differs not only in particular elements from the Hungarian national identity, but also in its structure. First of all there is the peculiarity that Csángó ethnic identity does not have separable elements which can readily replace other elements (e.g., 'religion' for 'language' or 'home village' for 'history'). The ethnic identity of the Csángós is an organic aspect of their traditional mode of existence as is their spiritual and material culture and their economic system. From this point of view it is clear that the Csángós' Catholicism is not simply the 'base component' of their identity but the projection of their religion that orders the whole of Csángó life and also appears in their ethnic identity. (Indisputably, because it is also an appropriate tool for opposing themselves to the neighboring Orthodox culture.) Another characteristic of this kind of identity is that it is essentially not an adapted but an inherited kind of identity. It is 'God's order' if someone is born to be Csángó or not. The Csángó children do not learn from their parents or at school how to be proper Csángós or what it means to be a Csángó, they simply 'found themselves like this' as they often phrase it, adding that this is their fate, as are the conditions of their life.

The other thing the Csángós could hardly understand was what their language had to do with Hungarian, i.e., why people thought that they would benefit from learning in Hungarian. One reason for this is that the only criterion for selecting the Csángó applicants for the Hungarian 'mother tongue' education was the acceptance of the name Csángó, forgetting (not knowing?) about the fact that about $75 \%$ of the Csángós are Rumanian monolinguals. Thus in the group of the Csángó students who were brought to Hungary to get their education in their mother tongue, there were always young people who could not understand a word of Hungarian, i.e., in their supposed 'mother tongue'. 
But even those who are bilingual differentiate their dialects from Hungarian (Tánczos 1997: 383). They usually call them Csángó, and although in some villages the vernacular dialect is called also magyar 'Hungarian', the perceived difference between the Csángó dialects and the Hungarian varieties is expressed by opposing the 'Csángó-way Hungarian' and 'pure Hungarian' (Sándor 1996a: 55,1996b: 61). The Csángós value their own dialects at an extremely low level. As 'the devil's tongue', it is forbidden in the church and as a 'bird's tongue' it is forbidden in the school. It is 'useless' in any official domain of language use, and even the Csángós themselves can have difficulties with the comprehension of another Csángó dialect. The traditional culture and values whose symbol is the vernacular dialect of the village might be important for elderly and middle aged people, but this attachment is not strong enough for them to pass on dialects which are associated with the feeling of being despised and threatened. Thus these older generations align themselves with the younger ones, who prefer to speak Rumanian, and for whom the traditional culture is associated with the backwardness of an old rural culture and poverty, and who want to step out of this culture, and feel ashamed because of it, and reject its symbols as well.

The Csángó pupils and students came from these generations. The organizers of the Csángó schooling action aimed to show the young Csángós that Hungarian was a prestigious language with a rich cultural background, assuming that this realization would help the students to stay Csángós. Actually the Csángó students did realize the values of Hungarian - and, at the same time, they discovered with complete certainty that this language is not the one they can speak. First of all, they can hardly understand the Carpathian Basin Hungarian varieties, just as their speakers can understand them only with difficulty. (On the Csángós' opinion of non-intelligibility between the Csángó and 'pure Hungarian' dialects cf. Tánczos 1995a: 153, 1995b: 64-65, 1996: 253-254.) From a linguistic point of view, the 200-500 years of isolation, and contact with Rumanian, explain the divergence of Csángó and Carpathian Basin Hungarian. In addition, the process of natural divergence was very much reinforced by the Hungarian language modernization movement of the 19th century, when thousands of new words were implanted in the Hungarian language. ${ }^{10}$ Also the Hungarian alphabet and spelling form a barrier to the comprehension of written Hungarian even for those whose Csángó dialect would make such written texts more or less understandable.

Besides the trouble caused by the lexical and grammatical differences the Csángó students must face a situation where their lack of knowledge of Hungarian special terminology is often equalled by their teachers' lack of knowledge about the subject. The teachers know even less about possible differences regarding Hungarian and the Csángó communicative competence, although there are major distinctions in this respect as well. The 
Csángó students do not and cannot know for instance, what variants to use in formal and informal styles, and they do not even know which situations are regarded to be formal or informal. They have different ideas about politeness and build on different 'common sense' presuppositions; they apply different strategies for expressing themselves and structuring their conversations; and they have a different underlying semantic system, a different set of structural metaphors, etc. The accommodating communities usually perceive these differences as lack of politeness and education or even as mental deficiencies.

In these circumstances the Csángó students can hardly understand why their own dialects are connected to the Hungarian language, which is hard for them to comprehend and almost impossible to speak and which, at least according to the expectations of their teachers, is to be respected. It is even worse when they come to understand the relationship between the Hungarian standard they are supposed to speak and the Csángó dialects. It is explained that their dialects are 'ancient', 'medieval' forms of Hungarian. People often praise 'the taste of old times' in them, but in both Transylvania and Hungary, the Csángó students ironically find themselves in a situation with which they are very familiar, namely that their vernacular is held in low esteem. In a normative country like Hungary, dialects are tolerated only in theory, meaning that although theoretically traditional dialects are welcomed, as soon as they are actually spoken they are stigmatized. Though Csángó is supposed to be the 'most beautiful ancient Hungarian', for the same people it is, of course, an 'undeveloped' version of Hungarian, which, in addition, is 'strongly corrupted' by Rumanian. Contrary to the assumptions of the action organizers, the perceived 'usefulness' and 'richness' of Hungarian strengthened rather than eliminated the Csángós' negative attitudes toward their own dialects, so their experiences actually block the reversal of the language shift of the Csángós.

Considering how unprepared the Csángó schooling action was, without any pedagogical and financial planning, and without applying any knowledge about the Csángós, the ultimate question that arises is why the organizers initiated the program at all? What was their real intention with the action if they did not even try to make it successful? According to Pálffy (1997: 5859) the action was first of all of a political nature. His notion is in agreement with Tánczos' view (1996: 187) that Hungarian politicians like using the Csángós for their own purposes. It is a fact that after 1945 it was not welcome in Hungary to mention the Hungarians outside Hungary, and so from 1990 on, because of this earlier repression, showing concern for the Hungarians outside Hungary could be a good political investment. Analyzing the events made for 'rescuing' the Csángós and the public discourses about them, it seems that some of the Transylvanian politicians acted according to the Hungarian pattern in showing concern for minority Hungarians living outside 
Hungary to prove their national commitment. The ultimate reasons of the failure of the Csángó schooling action can be found in this underlying motivation.

\section{'Let’s rescue the Csángós!'}

The Csángó schooling action is in fact embedded in a more extended network of actions which can be called the 'rescue' of the Csángós. All of these actions are based on the same notion, namely that the Csángós belong to the Hungarian nation but due to unfortunate historical processes they have forgotten about or do not dare to admit their Hungarian national identity (see, e.g., Pávai 1995). So, the main goal of all the 'rescuing' actions should be to make the Csángós aware of the fact that they are part of the Hungarian nation.

Originating from the fact that the cardinal point of the 'rescue' is not the revitalization of the Csángós' language but the revitalization of their Hungarian national feeling, the schooling action is only one element of the whole process. Although the idea of a 'resettlement' in Transylvania or Hungary has recently occurred only sporadically (about such attempts in 1883 and 1941 see Sándor 1998a, ms), dominant forms of late 20th century migration such as temporary or long term guest working by the Csángós in Hungary (Halász 1993: 172; Pozsony 1994: 11) are welcomed by the 'rescuers', as well as strange forms of tourism with the aim of the 'awakening' Hungarian national feeling in the Csángós. This tourism includes taking Csángó folkgroups, football teams, etc. to Hungary, as well as taking Csángós to the conference organized in honor of the Csángó researcher Pál Péter Domokos, to the visit of the Pope to Hungary, and to the Csíksomlyó feast (Transylvania), summer camping for Csángó children in Hungary (Szöcs 1993: 164), or even taking them to the funeral of the Hungarian prime minister. ${ }^{11}$

Another form of 'rescue' involves the introduction of Csángó culture to Transylvania and especially Hungary: in the electronic media, in special summer camps for pupils and students, and folk festivals. The idea of learning more about the Csángós is of course desirable and important. There is a danger, however, in the way the introduction is conducted, namely that people are offered an idealized picture of the Csángós. And there is also a danger in the fact that this is strongly connected to politics. ${ }^{12}$

It was Tánczos (1996: 174-189) who first called attention to the fact that the Hungarian mass media paint a rosy picture of the Csángós and that this does harm mostly to the Csángós. The idealized picture of the Csángós is so strong and uniform that it can safely be called a myth. Although the media can indeed be accused of publicizing the Csángó myth, the responsibility lies with 
Hungarian scholarship dealing with the Csángós. Lay opinions are often hard to separate from those of professional scholars, who make the Csángó myth even more established either on the basis of their conviction (i.e., partiality) or because of carelessness (i.e., with ambiguous phrasing).

According to the myth the Csángós still speak the Hungarian language of the 15th century, and they have a medieval spiritual and material culture, still in its pure, 'golden age' form, untouched by civilization. As pure as their culture is, so is their morality and religious life. Another part of the myth is that the Csángós have lived without any care and protection, but have safeguarded their valuable language and culture in spite of all restrictions. The myth has thus produced three underlying metaphors, namely 'traveling back through time', the 'orphan', and the 'hero'. (About the Csángó myth in details, and the citations of the texts the above statements are derived from, see Sándor 1998b)

These metaphors have proved to be extremely powerful. They control actions in connection with the Csángós and block the possibility of dispassionate examination of the situation and of factual aid. The myth suggests that there is no need for gathering and analyzing more data about the 'rescuees', since it offers a coherent, perfect picture without doubts or questions. Of course, this mythologized picture of the Csángós does contain some elements which resemble reality, so it can look rather realistic. On the other hand, the myth is heavily impregnated with national emotions, so those who are unwilling to describe the Csángós in compliance with the myth, may be condemned for having broken taboos. The exasperation present in the tone of the rescuers' texts is most probably motivated by a superstitious component of the Csángó myth. In 1920 the notion first appeared in the Csángó literature that the Csángós are 'the mark of the Hungarian minorities' fate' (Györffy 1920). The belief that the way the Hungarian political elite handles the Csángó question reveals their ideas about how they want to care about those millions of Hungarians who live outside Hungary, still holds (see, e.g., Beke 1994). The superstitious element was added to the myth with a rephrasing of this belief, saying that if the Csángós can be saved as Csángós, then Hungarian minorities can be saved as Hungarians. The most destructive outcome of the myth is that people who act according to the underlying metaphors, and who want to 'rescue' the Csángós and celebrate them as heroes, think they had done something important, although practically nothing has happened to improve their economic conditions or to achieve an improvement regarding human rights, or even to secure the rights for minority mother tongue education guaranteed by Rumanian law.

On the individual level, the myth has led to bitter experiences for Csángó pupils and students. Because of the false picture of the Csángós, people usually get very disappointed at the real Csángós' 'faulty' behavior, for 
instance when they hear the students (supposedly guardians of 'ancient Hungarian') speaking in Rumanian with each other; when they (supposed champions of religious morality) 'get pregnant and in addition they are arrant liars' (the words of a charity activist), etc. This disillusionment usually lends to punishment (even physically) of Csángó students rather than invalidation of the myth.

\section{Is there a possibility of revitalizing the Csángós’ language?}

In view of the sad outcome of the Csángó schooling action, and considering the conditions of the Csángós, the question arises as to whether there is any possibility at all of helping the Csángós to secure their linguistic and other human rights and improve their life conditions? Can we try to do this without having any idea about the possible results? Do we have the right to intervene in the life of the Csángós from the outside for any purpose? The last two questions, I think, we can answer with an irrefutable 'no' if aid were to mean what it has meant recently. First of all, those who plan actions to help the Csángós, should get rid of the influence of the Csángó myth and build their activities on facts and data. It is of cardinal importance to make sure that the Csángós themselves call in Hungarian or Transylvanian aid. As Kontra (1997: 124125) has remarked, any action, even the most well-intentioned and scholarly, hurts the Csángós' right to self-determination. Taking into account the present attitudes of the Csángós as well as the bitter experiences they have had resulting from the previous actions, demonstrating facultativity and graduality in the actions seems to be the principal requirement.

It is also important to change the revitalization of the Csángós' language from a national and political to a scholarly based program whose starting point is not an ambition to 'raise' the Csángós' language as a symbol of their attachment to the Hungarian nation (i.e., to teach them standard Hungarian), but the recognition that the Csángós, like any other ethnic group, have the right to keep their culture and dialects. There are many linguistic, cultural and social differences between the Csángó and Hungarian communities (in Transylvania and Hungary). There are also negative attitudes on the part of the Csángós towards the Székelys and sometimes also against anything connected to Hungarians. There is also a strong normative and stigmatizing tendency in Hungarian speech communities. It therefore does not seem reasonable to cover or 'roof' the Csángó dialects with the Hungarian standard, in other words teach the Csángós Hungarian in the frame of a revitalization process. Considering the circumstances, the reversal of the language shift of the Csángós and the stabilization of bilingualism could probably be accomplished on the basis of a koiné of the Csángó dialects. 
Many Hungarian academics are afraid of such an idea, and tend to regard it as a step toward the breakdown of the Hungarian nation. They fail to take into consideration the fact that the Csángós do not have any occasion to use standard Hungarian, as it is Rumanian that they have to speak in all standard functions. They cannot use standard Hungarian because there is no mutual intelligibility between it and their dialects; and it would be nonsense for them to use standard Hungarian with members of their own communities. Forcing them to learn standard Hungarian results in the diminishing of their Csángó ethnic identity. They need a language that they can accept as a symbol of their culture and that is linguistically close enough to their dialects so that its acquisition does not cause difficulties for them. If a Csángó koiné (standard) is not regarded as a non-standard dialect but an independent language in its own right, its stigmatization by speakers of Hungarian would be easier to avoid. (For the arguments for a Csángó koiné [standard] and about an attempt at writing a textbook in such a Csángó variety see Sándor 1996a)

The revitalization of Csángó is also certainly impossible without the contribution of the Rumanian state. The Csángós have for centuries been fearful of using their mother tongue, so, first of all, the assimilation policy of the state should cease. All the following steps, namely the elaboration of pedagogical projects for teaching Csángó, the creation of out-of-school forums on the use of Csángó, the graphization of Csángó, etc., can obviously be done only with the political and financial assistance of the Rumanian state. Sad to say, such a turn in Rumanian politics seems to be nothing more than a hopeful dream, at least in the near future.

The author of the present paper agrees with János Benedek's (1997a: 209) remark: 'It is a self-delusion to believe that in the long term the Csángós will keep the Hungarian language, and if we aid them only for this purpose, the aid can be stopped right now'. (However, I would maybe add 'at this moment' to make the sentence a little more optimistic.) Benedek suggests that aid should first of all be economic, but I think, together with it, it is also important to empower the Csángós to represent and protect their own interests. If the Csángós want them to do it, I find it natural that Hungarian scholars and politicians should make efforts to achieve this goal. In this case I see it as the main task of Hungarian Csángó studies to contribute, with unbiased surveys and rational rather than emotional analyses, to the resolution of the problems. And I see the main task of Hungarian politicians as acting not in the interests of a homogeneous Hungarian national idea but of linguistic and cultural plurality, and, above all, of a better life for the Csángós. 


\section{Notes}

I want to thank to Peter Trudgill for his comments on an earlier version of this paper, and for his help in formulating the English version of this text.

1. Although the relatively new data of the last Rumanian census (1992) could be used, its datagathering methods make the results rather undependable, at least in the case of the Csángós. Census-takers marked the Csángós' nationality as Rumanian asking loaded questions like 'You are Rumanian, aren't you?' (Csoma and Bogdánfalvy 1993). Estimates are based on the number of Catholic people in Moldavia, since all the Csángós are Catholics, and they are the only Catholic inhabitants. In popular Hungarian usage the name Csángó refers not only to these groups but also to others, e.g., for Hungarians in Bukovina (Northern Moldavia), in the Gyimes (Rumanian Ghimeş, valleys in the Carpathians around the Gyimes pass) or in Hétfalu ('seven villages'), near Brassó (Rumanian Braşov). Literature on the Csángós, however, differentiates these groups from the Moldavian Csángós on the grounds of their significantly dissimilar culture and dialects.

2. Several Hungarian noblemen are mentioned in Moldavian historical sources. Some of the voivodes had Hungarian wives (Benda 1989: 35-37). The evidence of Hungarian loanwords in Rumanian also shows strong Hungarian influence on urban life. Most of them are semantically connected to the administration of the court, legal system, military, and urban life, e.g., the words for 'brave warrior', 'sword', '(soldier's) pay', 'page', 'judge', 'inheritance', 'master craftsman', 'burgess', 'lay clerk', etc. (see Mikecs 1989: 156-157; and Benkö 1989: 287). The forefathers of the Csángós founded the town of Bacău (Hungarian Bákó) which, not much later, became an important trading center (Baker 1997: 677). They developed flourishing trading connections with Transylvanian and Polish towns and had the handicraft industry under their control (Benda 1989: 35-37) together with the Saxons who migrated to Moldavia from Transylvania with the Hungarians (Benda 1989: 10; Domokos 1987: 48), and played an important role in the urban life of Moldavia, both in industry and trading until the end of the 17th century by which time they had assimilated to the Rumanians or to the Hungarians (Benda 1989: 35).

3. Departmental decision 5023/24.05.1993 of the Rumanian Educational Ministry allows the minorities in Rumania to teach their mother tongues in 4 and 3 classes per week in elementary and highschools (Borbáth 1994: 219). Until now there has not been a single attempt to take this opportunity, most probably because in practice even private teaching is penalized.

4. Unfortunately, current descriptions of the status and especially of the corpus of Csángó dialects are remarkably inadequate. Previous studies concentrated more or less only on those features of the Csángó dialects which were different from standard Hungarian or which differentiated the Hungarian Csángó and the Székely Csángó varieties from one another. Informants were selected and data were gathered using traditional methods. As data were specifically selected to show clear differences, they seem not only insufficient but somewhat unreliable, too. (This seems to be true of the Atlas of the Moldavian Csángó Dialect as well.) The other side of the coin is that the conditions that fieldworkers must face in Moldavia severely hinder the collection of new data. After years of open political repression people are still afraid to get involved with anything associated with Hungarians. Recent events show that their fear is by no means without cause at all even today: people keeping up connections with Transylvania or Hungary can be publicly humiliated by the priest for their 'anti-national' behavior; in 1995 an ethnographer was held by the police for hours for having taken photos of the church and the cemetery, etc.

5. In 19958 interviews were tape-recorded in Cleja (Klézse), a village in the Southern Csángó area with a mixed Székely and non-Székely population. The fieldworker was one of my Csángó students, Antal Csicsó, who was born in the same village. The questionnaire he used 


\section{K. Sándor}

during the conversations was based on the questionnaire of 'The Sociolinguistics of Hungarian Outside Hungary' project (on this project see Kontra 1996), coordinated by Miklós Kontra and supported by the Research Support Scheme of the Higher Education Support Programme, grant number 582/1995.

6. In the case of the Csángós it seems to me relevant to differentiate between the processes of language revitalization and language revival as, e.g., Dorian (1994: 481) does. As with the revitalization of Quechua (Hornberger and King 1996), a condition for the revitalization of Csángó is also the reversal of language shift.

7. I want to thank Erzsébet Borbáth, head of the József Attila School, for sharing her experiences about the Csángó schooling action with me; I thank all participating teachers at the meeting on the education of Csángó pupils in Transylvania, organized in the summer of 1996, for their kind help.

8. These paragraphs are based on the interviews I made with the Csángo students of the Juhász Gyula Teacher Training College (Szeged), and with the students of the Kodolányi János Institute (Budapest) where the Csángó students spent a preparatory year before they began to study at a university. Fodor (1995) reports similar experiences.

9. When designating their flock, the Moldavian Catholic priests usually use romăn catolic ' $\mathrm{Ru}$ manian Catholic' instead of romano catolic 'Roman Catholic' to affirm the Rumanian national identity of the Csángós. This 'merging' can be interpreted as a symbol of the interpenetration of the Vatican's and the Rumanian state's interests in assimilating the Csángós. This subterfuge was practised by the Vatican as early as the middle of the 19th century (Lükö 1936: 16) with the aim of also acquiring a Rumanian flock. This ambition has been maintained until today (Tánczos 1996: 187), and could also serve the interests of the homogenizing intentions of the Rumanian nation state. To mention one case, in 1992, during the last Rumanian census, this linguistic similarity was used as the most powerful argument through which the priests 'convinced' their flock to identify themselves as 'Rumanians' (Csoma and Bogdánfalvy 1993: 165). On the Vatican's assimilating policy in connection to the Csángós, its purposes, forms, and historical aspects see Sándor (1999).

10. The Hungarian language modernization movement, connected strongly with the effort to achieve the right to use Hungarian (rather than German) in schools, and in academic and political life, aimed to make the Hungarian language suitable for uses in all domains of language use, and concentrated especially on the modernization of the vocabulary of the special registers in which Latin and German had been used before, as well as on the literary language. The modernization movement was led by writers and poets, who first used the new words, very often 'translating' them in a vocabulary attached to their books to enable readers to comprehend the texts. Many of the new words had a very brief life, but more than a thousand survived and are used in all dialects of present-day Carpathian Basin Hungarian.

11. The events above are listed as the most important successes by Péter Halász (1993: 169172), the leader of the Lakatos Demeter Society that defines itself as the organization which aims to coordinate Csángó studies. In the choreography of the funeral ceremony of the late József Antall (t 1992) Csángó children took an important role. (József Antall declared himself to be 'the prime minister of 15 million Hungarians', i.e., also the prime minister of Hungarians living outside Hungary, so the choreography of his funeral was built around the symbolic condolences of different subgroups from the 15 million, all wearing folk costumes.)

12. Both the President (Árpád Göncz) and the Prime Minister (József Antall) of Hungary participated in the first Csángó Festival organized in Budapest in 1991. (Csángó Festivals are two or three day occasions where Csángó folk music and dance are performed and taught to the audience, and usually also folkart products are sold.) Quite recently, in March 1998, Viktor 
Orbán, at that time president of the right-wing Fidesz-MPP, took on the patronage of the Csángó Festival as a part of his party's campaign.

\section{References}

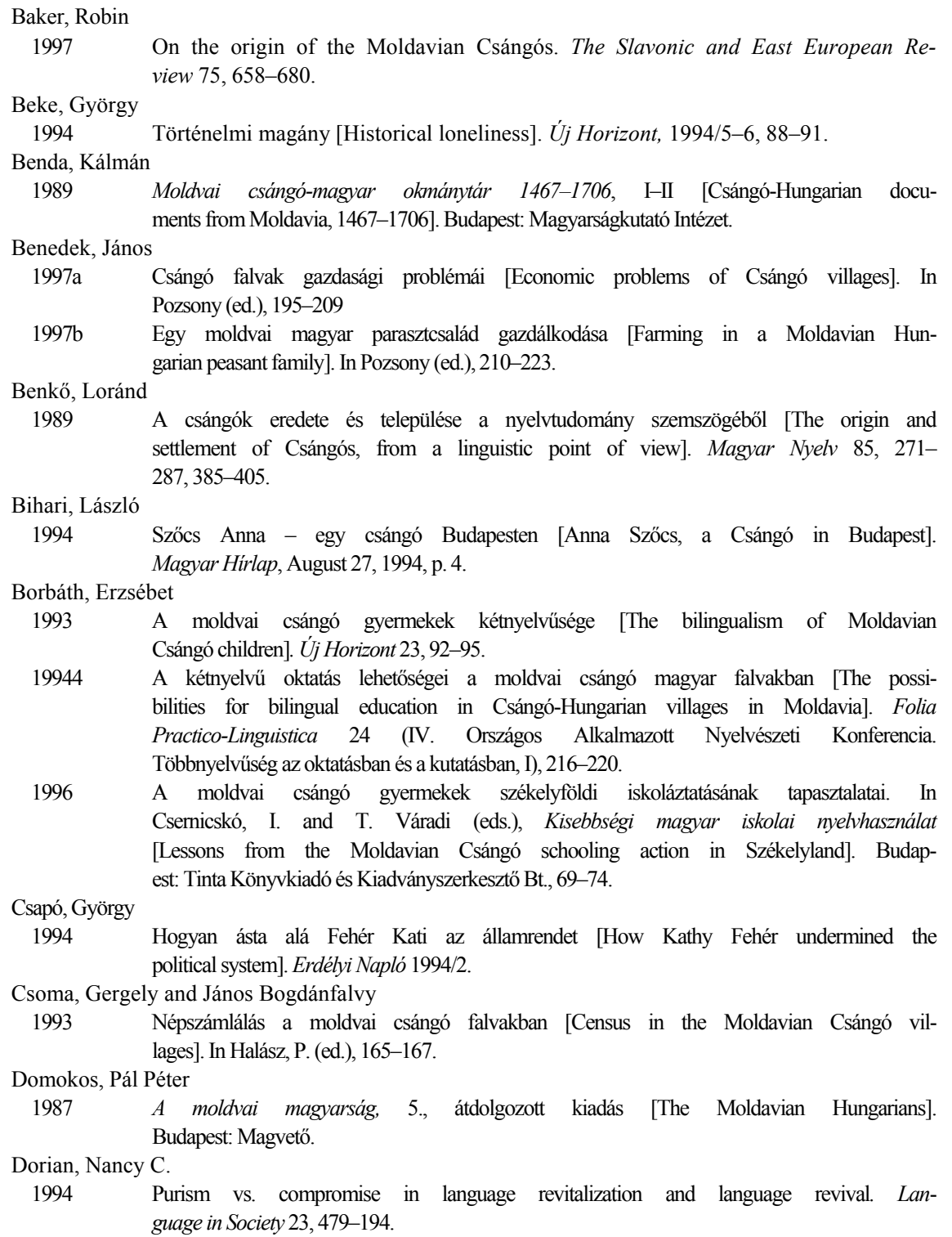


Fodor, Katalin

1995 A csángók identitásproblémájának nyelvi és nyelven kívüli okairól [On the linguistic and non-linguistic causes of the identity-problems of the Csángós]. In Kassai, I. (ed.), Kétnyelvüség és magyar nyelvhasználat. Budapest: az MTA Györffy, István Nyelvtudományi Intézete, 121-127.

$1920 \quad$ A

A romániai magyarság sorsa [The fate of the Hungarians in Rumania]. Manuscript.

Halász, Péter

1993 A Lakatos Demeter Egyesület [The Demeter Lakatos Association]. In Halász, P. (ed.), 169-173.

1994 Eredmények és feladatok a moldvai csángók néprajzi kutatásában. In Halász (ed.), $1-37$.

1997 Új szempontok a moldvai magyarok táji-etnikai tagozódásának vizsgálatához. In Pozsony (ed.), 7-26.

Halász, Péter (ed.)

1993 'Megfog vala apóm szokcor kezemtül...' Tanulmányok Domokos Pál Péter emlékére [Festschrift for Péter Pál Domokos]. Budapest: Lakatos Demeter Egyesület.

1994 Néprajzi látóhatár III/1-2 [Ethnographic research on the Moldavian Csángós: Results and tasks].

1997 Új szempontok a moldvai magyarok táji-etnikai tagozódásának vizsgálatához [New perspectives on the geographic and ethnic divisions among Moldavian Hungarians].

Hornberger, Nancy H. and Kendall A. King

1996 Language revitalization in the Andes: Can the schools reverse language shift? Journal of Multilingual and Multicultural Development 17, 427-441.

Kallós, Zoltán

1993 Gyüjtési élményeim Moldvában [My fieldwork experiences in Moldavia]. In Péterbencze, A. (ed.), Moldvának szíp tájaind születtem. Jászberény: Jászberényi Múzeum, 95-109.

Kapaló, James

1994 Közelebb a csángókhoz [Getting closer to the Csángós]. Müvelödés 3, 30-31.

Kontra, Miklós

1996 Magyar nyelvhasználat határainkon túl túl [Hungarian language use beyond Hungary's borders]. In Diószegi, L. (ed.), Magyarságkutatás 1995-96. Budapest: Magyarságkutató Intézet, 113-123

1997 Magyar vonatkozású széljegyzetek A Nyelvi Jogok Egyetemes Nyilatkozatához [Hungarian comments on the Universal Declaration of Linguistic Rights, Barcelona, 1996]. Iskolakultúra 11, 122-127.

Kotics, József

1997 Erkölcsi értékrend és társadalmi kontroll néhány moldvai csángó faluban [Moral values and social control in some Moldavian Csángó villages]. In Pozsony (ed.), $36-55$.

Lükő, Gábor

1935 Havaselve és Moldva népei a X-XII. században [The peoples of Wallachia and Moldavia in the 10-12th centuries]. Ethnographia 46, 90-105.

1936 A moldvai csángók. I. A csángók kapcsolatai az erdélyi magyarsággal [The Moldavian Csángós]. Budapest. 


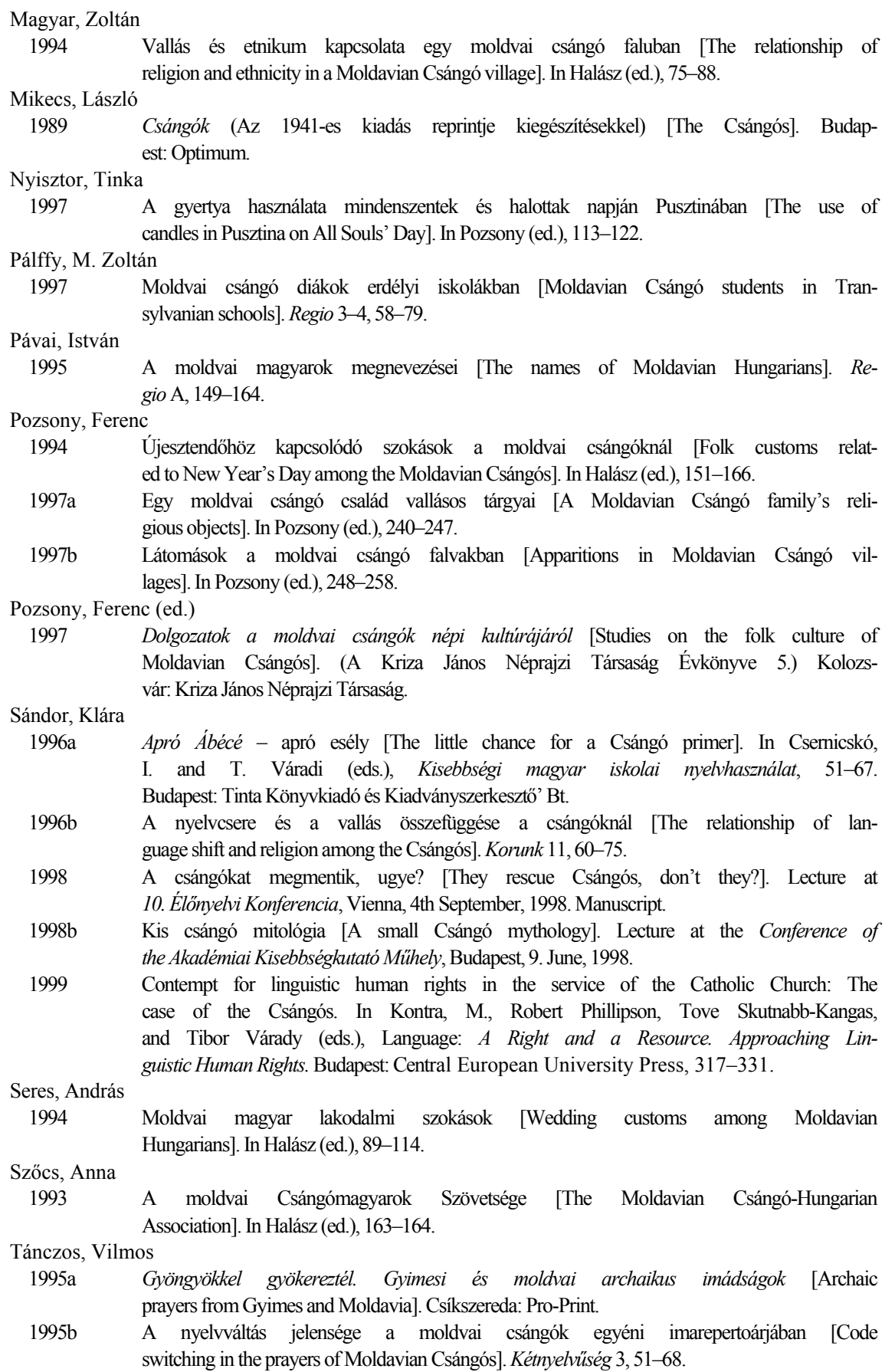




\section{K. Sándor}

1996 Keletnek megnyílt kapuja [Folklore essays]. Kolozsvár: Korunk Baráti Társaság.

1997 Hányan vannak a moldvai csángók? [How many Moldavian Csángós are there?]. Magyar Kisebbség 3, 370-390.

Thomason, Sarah Grey and Terrence Kaufman

1988 Language Contact, Creolization, and Genetic Linguistics. Berkeley/Los Angeles/Oxford: University of California Press.

Virt, István

1994 Halál és emlékezés (Halottak napi szokások a Bákó megyei Pusztinában) [Death and remembrance: Customs related to All Souls' Day in Pusztina, Bákó County]. In Halász (ed.), 125-134. 